\title{
APICULTURE: A TOOL OF SELF EMPLOYMENT
}

\author{
V. K. Rewatkar* \\ Department of Botany, Shri. Dnyanesh Mahavidyalaya, Nawargaon, Chandrapur- 441223 \\ M.S. \\ Email- vasantirewatkar29@gmail.com
}

Communicated : 12.07 .19

Revision :21.07.19 \& 21.08.19

Accepted : 14.09.19

Published: 30.09.19

\begin{abstract}
:
Every institution would like to be recognized for certain of its attributes which make it "distinct" or one of its kinds that are reflected in all its activities in focus and practice. The focus of NAAC, as the vision statement says about quality and quality culture by HEI in terms of three markers; quality initiative, quality sustenance and quality enhancement which may be institutionalized. The best practice in an HEI can be resulted into high value impact on any aspect of educational and social activity in that institution. Thus the 'Best Practice' must be value-added practice, when it shows its sustenance in the present day setup of fast-paced educational innovation. The practice can be identified as the best practice when it satisfies the maximum stake holders (students, teacher, parent, Alumni and employee). Modern age is called an economic age in which money plays an important role. The development of people, the society and the nation is depend upon the sources of income. In the village number of people live with minimum fascilities as poverty and unemployment are the main features of rural India. The number of job seekers is increasing day by day and government cannot afford jobs to all of them in public sectors. Hence way of self employment is the solution to reduce this problem. 'Apiculture' can ensure enhancement of family income at less investment and more profit. Apiculture is the commercial production of honey (which has been an important element in the sweet diet of man) and bees wax using modern scientific and commercial method. 'Apis' is the generic name of honey bees. In India Bee Culture or Apiculture is practiced as Cottage industry providing employment to lakhs of people.
\end{abstract}

\section{INTRODUCTION:}

The Revised Accreditation Framework (RAF) of NAAC is based on five core values like Contributing to National Development, Fastering Global Competencies among Students, Inculcating a Value system in students, Promoting the use of Technology and Quest for Excellence. Hence the practice should follow the core values and should have a good satisfactory result, durability, scope for reproduction, scope for improvement and participation or involvement of all stakeholders (1). The practice should run for many years continuously i.e. more than five years and must sustain over a considerable period of time.it is also important that the practice must lead to measurable outcomes affecting a large number of beneficiaries. Identifying the local resources in the vicinity and to develop it into best practice should be the aim of every HEI. To develop Apiculture as the "Best Practice" of Shri Dnyanesh Mahavidyalaya identified more nectar yielding plants like - Neem (Azadirecta indica), Jamun (Syzygium cumini) , Sheesham (Dalbergia sissoo), guava (Psidium guajava) for pollen grains and the best quality Bees. The place where honey bees are kept is called Apiary.

\section{Selection of honey bees:}

Selection of honey bees is an important step of Apiculture. The honey bees for apiculture must have high yielding capacity, must be able to 
form the hive anywhere, worker bees must be smart and energetic, they must be able to protect themselves from the enimies and must possess colonial habit.

\section{Species of honey bees:}

There are 20,000 species of wild bees (2). Many species are solitary (3). In India four common species of honey bees are found viz. Apis indica, Apis dorsata, Apis florea and Apis mellifera. Out of these four Apis indica is the best suited for Indian climate.

\section{The bee colony:}

The nest of honey bee is known as the bee hive. The 19th century produced an explosion of innovators who perfected the design and production of bee hives (4). The population of an average sized colony consists of 30 to 50 thousand individuals.

\section{Castes:}

A colony of bees consists of three castes of bees-

- A Queen Bee: This is only breeding female. It is diploid. At the peak of breeding season- late spring to summer, a good queen may lay 3000 eggs a day but a more average queen might lay just 1000-1500 eggs per day. The queen has a sting, curved like sword at the tip of abdomen. Her legs are strong. She is fed a larger amount of royal jelly resulting in a radically different growth and metamorphosis. The queen influences the colony by production and dissemination of a variety of 'queen substances'pheromones' which suppresses the development of ovaries in all the female worker bees and prevent them from laying eggs.

- The worker bee: It is diploid sterile female and smallest among all the other castes. The functions of worker bee are collection of honey, production of royal jelly, cleaning the comb, making wax, raising larvae and young ones, defending and protecting the hive. Worker bees are- Laying workers, Nurse workers, House workers and Field workers.

- The Drone Bee: it is haploid and fertile male. They are born out of unfertilized eggs. They have large wings, robust body, larger than workers and have reduced mouthparts. They are stingless. The main function of drone bee is to fertilize the queen during the 'Nuptial flight' after which they are starved to death.

\section{Essential elements:}

There are some essential elements for modern beekeeping, they are

1. Typical moveable hive

2. Safety dress- protective clothing

3. Smoker

4. Knife or hive tools

5. Honey extractor

\section{MATERIAL \& METHODS}

The method of apiculture is based on scientific facts which have been developed after the extensive studies of bee behavior, their functioning and mode of reproduction.

Apiculture: Best Practice

Identifying local resources in the vicinity and to develop it into best practice should be the aim of every HEI that leads to positive impact on the regular functioning of the institution.Shri. Dnyanesh Mahavidyalaya, Nawargaon is situated in the remote and backward region of Eastern Vidarbha Zone (Maharashtra) in Chandrapur district. This region has dense forest having variety of Biodiversity. Human resources in the institution are students belonging to agriculture background. Since the prehistoric times the importance of honey was known to mankind of the world. The previous method of collection of honey was to go to the forest in search of hives bee. After getting that the honey collectors, used to apply smoke or fire for driving away the bees from hives and 
then collect honey and wax. To make students self employable and to start source of income for rural graduate students, our institution started certificate course in Apiculture. The curriculum of the certificate course was designed by Zoology Department. The duration of this course was limited to three months. The teaching along with practical was catalyzed into action and the systematic plan was instituted to provide pure honey to villagers at reasonable cost.

\section{Evidence of Success:}

Many students in the vicinity have started the Apiculture project in their farms. The pure honey and wax have increasing demand from local people.

\section{Threats to Beekeeping:}

Diseases, Pests and Predators:

Diseases: Honey bees have diseases that affect adult bees only. They are Sacbrood caused by virus, Chalkbrood caused by fungus (Ascosphaera apis), Nosema disease caused by Microsporidian, Acarapis disease caused by mites

Pests: Pests are Greater Wax Moth, Lesser Wax Moth, bee louse, Ants, Termites, Dragon flies, Praying Mantises, Ambush bugs and certain Wasps are the natural enemies of honey bees.

Predators: mice, Skunks and Bears are the predators of bees (5).

Colony Collapse Disorder(CCD) is sudden colony death with a lack of healty adult bees inside the hive(6).

\section{CONCLUSION:}

A best practice is a method that has been generally accepted as superior to any alternatives because it produces result that change educational institute and society as well. NAAC has been striving hard to include its scope of assessment by promoting skill development of students and to explore newer local resources. So NAAC needs to examine the role of HEIs in preparing the students to face global challenges successfully and to prepare them for self employment.

The earlier process of honey collection was destructive and unhygienic where the hive was crudely broken into, using smoke to suppress the bee, the honey comb were torn out and smashed up along with the eggs, larvae and honey the contained. In the modern techniques, the beekeeping practice completed through the perfection of the movable comb hive which can be used again and again. When the climatic conditions are not suitable, the hive can be transferred to other safer area, so the protection of bees is better and easy in this method. Thus large quantity of pure honey can be obtained which gives more profit to the owner.

\section{REFERENCES:}

Manual for affiliated UG, PG Colleges, Dec. 2019

Geldmann, Jonas, Gonza'lez-Varo, Juan P. (2018) “Conserving honey bees do not help wild life", Science 359 (6374) 392-393.

Petro Prokopovych, Kyiv, Ukraine" Place in the world of beekeeping" Jan. 26, 2013, The Beekeepers Quarterly (Liverpool UK), Vol., 111. P.49-53

Michener, Charles Duncan (1974) : The social behavior of the Bees": A comparative study. Harvard University Press, PP 22-78, ISBN 978-0-674-81175-1.

What are some predators of the honey bee? Sciencing Com. Retrieved 2019.11.19 Johnson, Renee (2010) Honey Bee Colony Collapse Disorder.

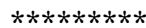

